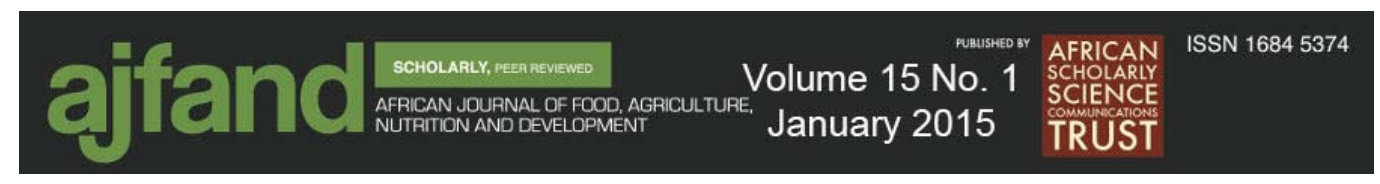

\title{
KNOWLEDGE OF RECOMMENDED DIETARY CHOLESTEROL ALLOWANCE IN AN ACADEMIC COMMUNITY
}

\section{Anyasor GN ${ }^{1 *}$, Adetunji $\mathrm{JA}^{1}$, Ibrahim $\mathrm{HO}^{1}$ and A Adekunle ${ }^{2}$}

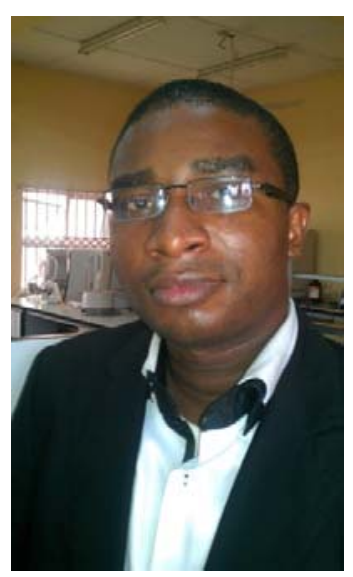

Godswill Anyasor

*Corresponding author email: anyasorgodswill@,gmail.com / anyasorgodswill@yahoo.com

${ }^{1}$ Department of Biochemistry, Benjamin S. Carson School of Medicine, College of Health and Medical Sciences, Babcock University, Ilisan Remo, Ogun State, P.M.B. 21244 Ikeja, Lagos, Nigeria

${ }^{2}$ Department of Computer Science and Mathematics, School of Science and Technology, Babcock University, Ilisan Remo, Ogun State, P.M.B. 21244 Ikeja, Lagos, Nigeria 


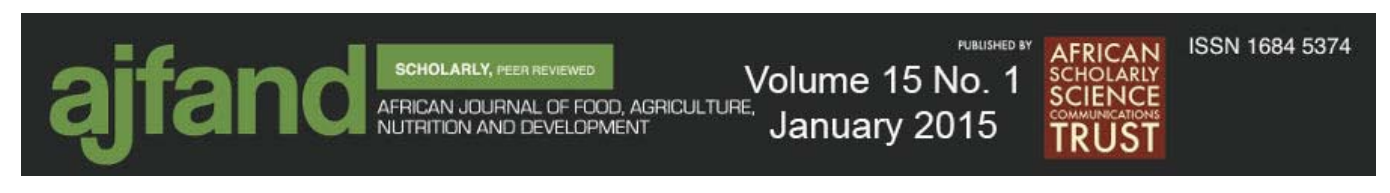

\section{ABSTRACT}

This study was designed to assess the plasma cholesterol level and consumer awareness of recommended dietary cholesterol allowance in an academic environment. A total of 100 structured questionnaires were randomly distributed within Babcock University community, Ilisan Remo, Ogun State, Nigeria. Ninety seven (97) completed questionnaires were retrieved. Venous blood samples of 60 volunteered participants were also collected for biochemical assays involving plasma levels of total cholesterol, low density lipoprotein (LDL) cholesterol, high density lipoprotein (HDL) cholesterol, triglyceride and glucose concentrations. Results showed that 53(54.6\%), 75(77.3\%) and 74(76.3\%) of the females, nonvegetarians and respondents in sciences, respectively had previous knowledge of the term "dietary cholesterol". Females 34(35.1\%), non-vegetarians 48(49.5\%) and respondents in sciences 50(51.5\%), respectively were aware of the negative effect of excess dietary cholesterol consumption. In addition, 35(36.1\%), 64(66\%) and $40(41.2 \%)$ of females, non- vegetarians and respondents in sciences consumed poultry eggs at least once a week. Males 35(36.1\%), females 35(36.1\%), nonvegetarians 54(55.7\%) and respondents in sciences $61(62.9 \%)$ had never checked their blood cholesterol level. Males 31(32\%), non-vegetarian 47(48.5\%) and respondents in sciences $40(42.2 \%)$ were not aware of the recommended dietary cholesterol allowance and they ate fried foods and confectionaries sometimes. Further study revealed that mean plasma total cholesterol $(141.73 \pm 20.51 \mathrm{mg} / \mathrm{dl})$, LDLcholesterol $(69.80 \pm 9.86 \mathrm{mg} / \mathrm{dl})$, triglyceride $(209.16 \pm 15.58 \mathrm{mg} / \mathrm{dl})$, and glucose $(52.27 \pm 7.94 \mathrm{mg} / \mathrm{dl})$ concentrations in males were slightly elevated compared to the total cholesterol $(141.36 \pm 9.75 \mathrm{mg} / \mathrm{dl})$, triglyceride $(205.43 \pm 6.55 \mathrm{mg} / \mathrm{dl}), \mathrm{LDL}-$ cholesterol $(55.52 \pm 4.03 \mathrm{mg} / \mathrm{dl})$ and glucose $(48.93 \pm 3.18 \mathrm{mg} / \mathrm{dl})$ concentrations in females while HDL-cholesterol concentrations of males $(30.10 \pm 11.96 \mathrm{mg} / \mathrm{dl})$ were significantly lower $(\mathrm{P}<0.05)$ compared to those of females $(44.75 \pm 9.21 \mathrm{mg} / \mathrm{dl})$. Plasma lipid and glucose concentrations of the respondents under the normal body weight category were significantly low $(\mathrm{P}<0.05)$ compared to those in overweight and obese body weight categories. Thus, this investigation indicated an inadequate level of awareness and practice of the recommended dietary cholesterol allowance among the educated.

Key words: Cholesterol, diet, glucose, knowledge, institution 


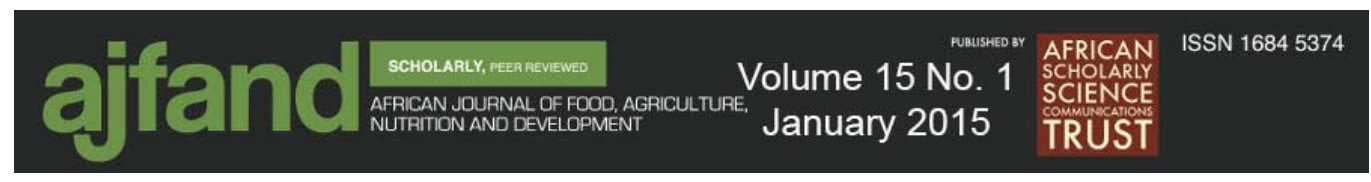

\section{INTRODUCTION}

Cholesterol is a fat-like substance, found in the blood stream, body organs and nerve fibres. It is a vital constituent of cell membranes and also a precursor of steroid hormones and bile salts [1]. Most cholesterol in the body is made by the liver from a wide variety of foods, but especially from saturated fats, such as those found in animal products. Dietary cholesterol, cholesteryl esters, and triacylglycerols are transported in the blood by intestinally synthesized chylomicrons [2]. There are three major classes of lipoproteins found in the serum of a fasting individual: low density lipoproteins (LDL), high density lipoproteins (HDL), and very low density lipoproteins (VLDL). Another lipoprotein class, intermediate density lipoprotein (IDL), resides between VLDL and LDL. In clinical practice, IDL is included in the LDL measurement [3]. After removal of their triacylglycerols at the peripheral tissues, the resulting chylomicron remnants bind to specific liver cell remnant receptors and are taken up by receptor-mediated endocytosis. In the liver, dietary cholesterol is either used in bile salt biosynthesis or packaged into VLDL for export [4]. While LDL transports cholesterol from the liver, cholesterol is transported back to the liver by HDL [2].

Cholesterol is clearly essential to life, yet its deposition in arteries has been associated with cardiovascular disease (CVD) and stroke, two leading cause of death in humans [5]. In fact, mortality forecasts predict that deaths due to CVD will represent more than $50 \%$ of total mortality in 2030 [6]. Furthermore, the risk of heart attack is three times higher in those with hypercholesterolemia, compared to those who have normal blood lipid profiles [7]. The World Health Organization delineated that unhealthy diets including those high in fat, salt and free sugar, and low in complex carbohydrates, fruits and vegetables can lead to increased risk of cardiovascular diseases $[8,9]$.

Research has shown that a diet rich in saturated fat content, heredity, and various metabolic conditions such as type II diabetes, influences an individual's level of cholesterol. Diets with reduced content of fatty acids and high carbohydrate have been widely recommended as a way to reduce the risk of coronary heart disease. This is because saturated fat increases LDL-cholesterol levels [10]. However, low fat, high carbohydrate diets also reduce HDL-cholesterol levels and elevate fasting levels of triglycerides. Low levels of HDL-cholesterol and high levels of triglycerides independently increase risk of lipid related diseases [10]. Vegetarian diets have been found to drop by $13 \%$ to $14 \%$ in LDL-cholesterol over six months and also foods with known cholesterol-lowering properties such as nuts, soy, and barley have been shown to be effective in lowering serum cholesterol in metabolically controlled conditions [11].

The American Heart Association (AHA) recommends that healthy adults should limit their dietary cholesterol intake to less than $300 \mathrm{mg} /$ day on average and individuals with high LDL- cholesterol, diabetes and/or CVD to reduce their dietary intake of cholesterol including eggs to less than $200 \mathrm{mg} /$ day [12]. The National Cholesterol Education Program recommends reduction in egg yolk consumption to 2 eggs per 


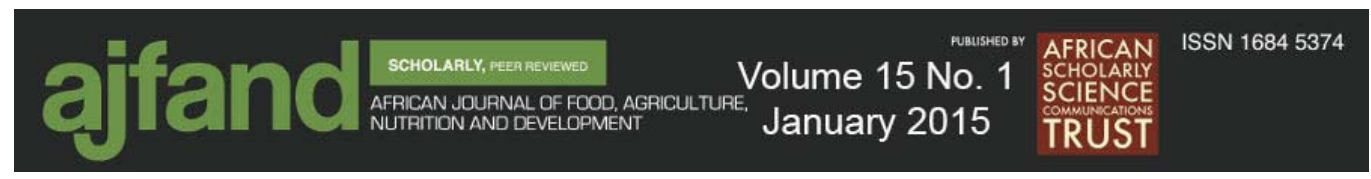

week as a way to reduce LDL cholesterol in individuals at increased risk of coronary heart disease [13]. Eggs are a major source of dietary cholesterol, with a typical egg containing on average $200 \mathrm{mg}$ of cholesterol [14]. However, it is also a complete food and an inexpensive and low calorie source of high quality protein and other important nutrients, such as minerals, folate and B vitamins, carotenoids, saturated (1.5 g/egg), polyunsaturated $(0.7 \mathrm{~g} / \mathrm{egg})$, and monounsaturated $(1.9 \mathrm{~g} / \mathrm{egg})$ fatty acids which could reduce the risk of CVD [15]. Current data on the effects of dietary cholesterol on serum cholesterol are inconsistent, ranging from positive association to no effects [14].

The Food and Drug Administration (FDA) also proposed a number of guidelines to address the problem of unhealthy eating behaviour. Among these recommendations is the education of consumers [16]. These guidelines, however, could only be effective if people altered their dietary behaviour [13]. Nutritionrelated knowledge can range from an understanding of the chemical structure of nutrients to knowledge of a low-fat diet. The three types of knowledge identified are awareness, principles, and practice [13].

Observational reports suggest that many Nigerian consumers may not fully understand the role of dietary cholesterol in disease progression or prevention. In addition, some consumers may regard all fats as bad [17]. A better nutrition knowledge about diet-disease relationships can help promote more healthful dietary choices and enhance health literacy among consumers [18]. There is little or no information in the literature about the characteristics of Nigerians who are aware or unaware of the appropriate dietary cholesterol allowance and those who are aware do little or nothing to follow dietary recommendations. Therefore, the purpose of this study was to assess the cholesterol level of respondents and their knowledge and practice regarding consumption of dietary cholesterol.

\section{MATERIALS AND METHODS}

\section{Study area and research instrument}

A cross-sectional study was conducted at Babcock University, Ilisan Remo, Ogun State, Nigeria. The members of Babcock University community constitute academic and non-academic staff, undergraduate and postgraduate students and were all included as part of the selection criteria. A well-structured questionnaire covering bio-data, diet type, discipline, occupation, knowledge of dietary cholesterol, frequency of consumption of food rich in cholesterol, and medical check-up was used as an instrument for this study. It was administered randomly to 100 healthy volunteered individuals ( 30 undergraduate, 30 postgraduate, 20 teaching and 20 nonteaching staff). All participants were adequately oriented about the procedures, risks and benefits involved and their informed consents were obtained.

\section{Collection of blood samples}

Fasting whole blood samples $(5 \mathrm{ml})$ were drawn from participants using plastic hypodermal syringe through venipuncture into fluoride oxalate bottles to prevent blood from clotting and to retard glucose catabolism. Immediately, the whole blood 


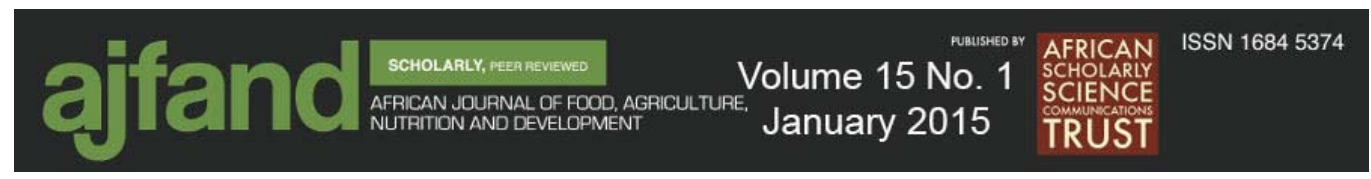

was centrifuge using a table top centrifuge (Uniscope, Model SM 112, Surgifriend Medicals, England) at 3500 revolution per minutes for $10 \mathrm{~min}$ to separate plasma for biochemical assays: the assessment of plasma lipid profile and glucose concentrations of participants [9].

\section{Lipid profile and glucose level estimation}

The plasma lipid profile and glucose concentrations were estimated using a spectrophotometric method with the aid of ACUREX kits (ACUREX Diagnostics, USA) for high density lipoprotein cholesterol, total cholesterol, triglyceride and glucose while low density lipoprotein cholesterol was calculated using the Friedewald formula [19], which is :

LDL cholesterol $(\mathrm{mg} / \mathrm{dl})=$ Total cholesterol- $($ Triglycerides $/ 5+$ HDL cholesterol $)$

\section{Body Mass Index (BMI) (Quetelet's index)}

The various weights $(\mathrm{kg})$ and heights $(\mathrm{m})$ of the participants were measured using beam weighing balance and stadiometer, respectively. The values obtained were used to compute the body mass index using the standard formula: BMI $\left(\mathrm{kg} / \mathrm{m}^{2}\right)$ = weight $(\mathrm{kg}) /$ height $\left(\mathrm{m}^{2}\right)$. BMI is significantly correlated with the total body fat content and is independent of sex. An individual within the BMI below 18.5 is considered as underweight; $18.5-24.5$ is normal $25.5-29.5$ is overweight; 30.5 40.5 is obese and greater than 40.5 is severely obese [20].

\section{Statistical analysis}

Respondent's data were represented and analyzed using SPSS for Windows; SPSS inc., Chicago, Standard version 17.0. Descriptive analysis in terms of frequency and percentage were performed on retrieved questionnaire data. Paired sample t-test analysis was carried out between mean plasma cholesterol levels- and gender while One way Analysis of Variance (ANOVA) was done between the various body mass index categories and the plasma cholesterol levels and the method of least significant difference was adopted for the post hoc analysis. Correlation analysis between lipid profile and glucose concentrations was also measured. Data were reported as percentages, mean \pm standard deviation.

\section{RESULTS}

Table 1 showed that 97 completed questionnaires were retrieved, out of which 44 and 53 were males and females, respectively with their ages ranging from $15-70$ years. The completed questionnaires revealed that the respondents were $80(82.5 \%)$ Christians, $16(16.5 \%)$ Islam and $1(1 \%)$ belonging to other religious persuasion. The marital category showed $61(62.9 \%)$ singles, $30(30.1 \%)$ married and $6(6.2 \%)$ divorced (Figure 1; Table 1). 

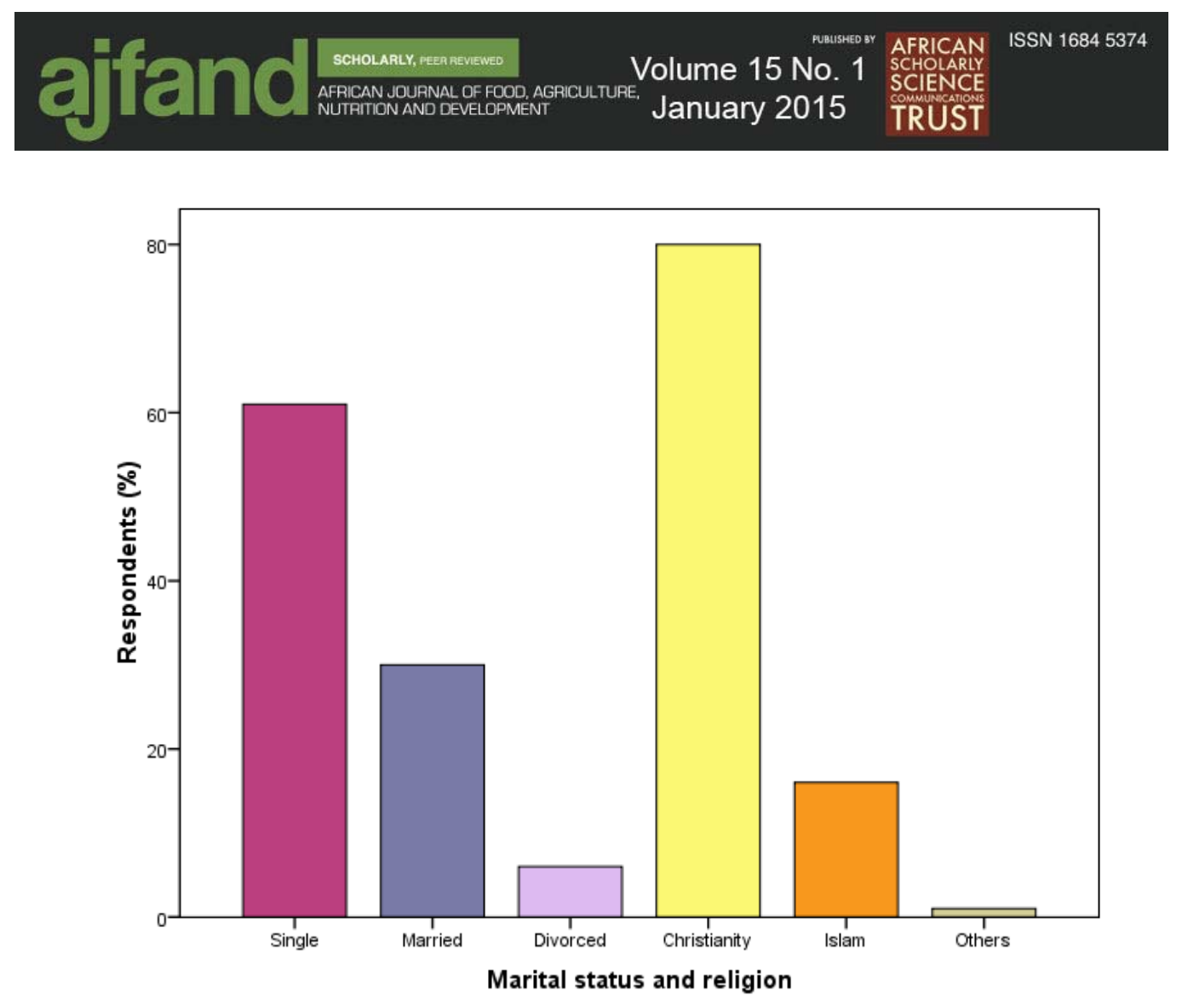

Figure 1: Respondents' data on percent marital status and religion

Table 1 showed that $44.3 \%$ and $54.6 \%$ of males and females, respectively had previous knowledge of the term "dietary cholesterol". However, 27.8\% and 35.1\% of males and females, respectively were aware of the negative effect of excess dietary cholesterol consumption.

Furthermore, $41.2 \%$ male and $50.5 \%$ females ate poultry eggs while $19.6 \%$ and $36.1 \%$ of males and females, respectively ate egg once in a week. None of the female participants ate poultry egg once a day while $5.2 \%$ males ate poultry egg once a day. However, $1.2 \%$ and $12.4 \%$ of females ate the whole egg and the egg white part, respectively compared to their male counterparts (Table 1).

A significant proportion of males (36.1\%) and females (36.1\%) respondents had never checked their blood cholesterol level, while those that were not aware of AHA recommended dietary cholesterol allowance were $32 \%$ and $27.8 \%$ males and females respondent, respectively.

Females $(50.5 \% ; 41.2 \%)$ and males $(42.3 \% ; 28.9 \%)$ ate fried foods and confectionaries, respectively. The participants $(84.5 \%)$ who had previous knowledge of dietary cholesterol and its negative effects had attended tertiary institution and they were mostly students and teachers, respectively. Those that attended tertiary institution (71.1\%) consumed whole egg. However, 8.2\% student and $6.2 \%$ teaching staff consumed the egg white part alone. Furthermore, $63.9 \%, 65.5 \%$ and $50.5 \%$ of those that had attended tertiary institution, teaching staff and students, 


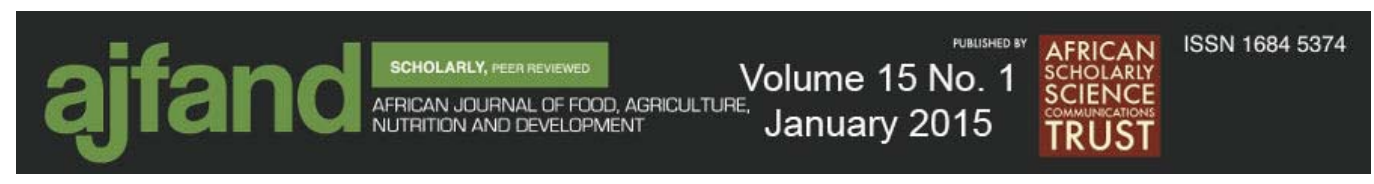

respectively had never checked their blood cholesterol level. Those that had attended the tertiary level, teaching staff and students were aware of the recommended dietary cholesterol allowance level and they also ate fried foods and confectionaries (Table 2).

Among the diet types and academic disciplines, non-vegetarians $(77.3 \% ; 49.5 \%)$ and those that studied sciences $(76.3 \% ; 51.5 \%)$ had knowledge of the negative health effect of exceeding the recommended dietary cholesterol allowance during meal (Table 3). The non- vegetarians $(71.1 \% ; 66.0 \%)$ and those in sciences $(73.2 \% ; 61.1 \%)$ ate more poultry egg and the whole egg respectively. Non-vegetarians $(55.7 \%)$ and $62.9 \%$ of those in sciences never checked their blood cholesterol level. Nonvegetarians $(48.5 \%)$ were not aware of the recommended dietary cholesterol allowance while $36.1 \%$ of those in sciences were aware of the recommended dietary cholesterol level. The non-vegetarians $(71.1 \% ; 51.1 \%)$ and those in sciences $(73.2 \%$; $52.6 \%$ ) ate more fried foods and confectionaries, respectively (Table 3 ).

The plasma total cholesterol $(141.73 \pm 20.51 \mathrm{mg} / \mathrm{dl})$, LDL-cholesterol $(69.80 \pm 9.86$ $\mathrm{mg} / \mathrm{dl})$, triglyceride $(209.16 \pm 15.58 \mathrm{mg} / \mathrm{dl})$, and glucose $(52.27 \pm 7.94 \mathrm{mg} / \mathrm{dl})$ concentrations in males were slightly higher compared to the total cholesterol $(141.36 \pm 9.75 \mathrm{mg} / \mathrm{dl})$, triglyceride $(205.43 \pm 6.55)$, LDL-cholesterol $(55.52 \pm 4.03$ $\mathrm{mg} / \mathrm{dl})$ and glucose $(48.93 \pm 3.18 \mathrm{mg} / \mathrm{dl})$ concentrations in females (Figure 2). More so, the HDL-cholesterol concentrations in males $(30.10 \pm 11.96 \mathrm{mg} / \mathrm{dl})$ were significantly lower $(\mathrm{P}<0.05)$ than those in females $(44.75 \pm 9.21 \mathrm{mg} / \mathrm{dl})($ Figure 2$)$.
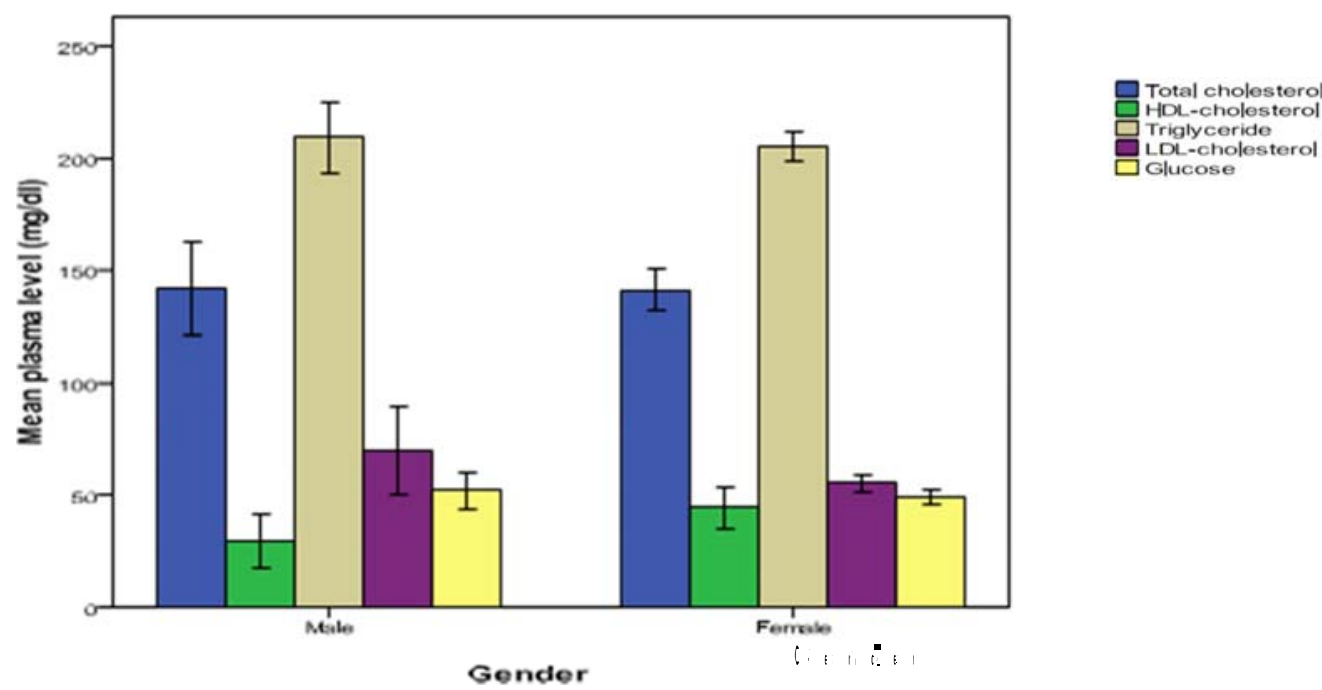
Triglyceride Glucose

Figure 2: Mean concentrations of plasma lipids and glucose in male and female respondents 

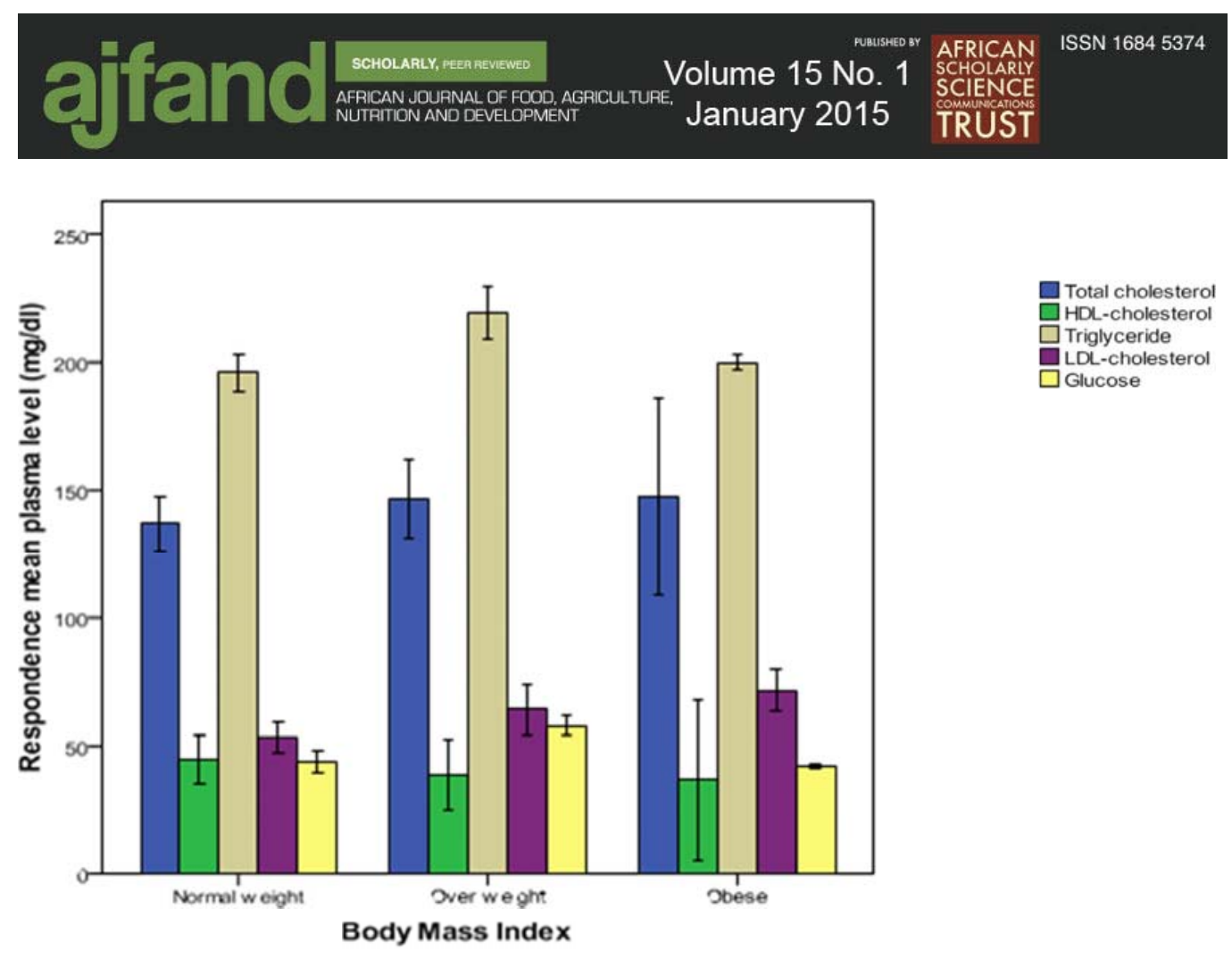

Figure 3: Mean concentrations of plasma lipids and glucose against the body mass index of respondents

Furthermore, plasma total cholesterol $(136.61 \pm 10.64 \mathrm{mg} / \mathrm{dl})$, LDL-cholesterol $(52.67 \pm 6.04 \mathrm{mg} / \mathrm{dl})$, triglyceride $(195.79 \pm 7.29 \mathrm{mg} / \mathrm{dl})$, HDL-cholesterol (44.78 $\pm 9.47 \mathrm{mg} / \mathrm{dl})$ and glucose $(43.75 \pm 4.39 \mathrm{mg} / \mathrm{dl})$ concentrations of the respondents under the normal body weight category were significantly lower $(\mathrm{P}<0.05)$ compared to those in overweight $(146.11 \pm 15.52,63.69 \pm 9.75,219.10 \pm 10.25,38.61 \pm 13.73$ $\mathrm{mg} / \mathrm{dl}$ and $57.54 \pm 3.78 \mathrm{mg} / \mathrm{dl}$, respectively) and obese $(147.41 \pm 38.60,71.13 \pm 8.09$, $200 \pm 3.26,36.28 \pm 31.16$ and $41.77 \pm 0.92 \mathrm{mg} / \mathrm{dl}$ ) categories (Figure 3 ). Result also showed that there was a significant $(\mathrm{P}<0.01)$ correlation between the LDLcholesterol, HDL-cholesterol and total cholesterol concentrations. Glucose concentration level also correlates significantly $(\mathrm{P}<0.05)$ with LDL-cholesterol (Table 4).

\section{DISCUSSION}

High blood cholesterol (hypercholesterolemia) especially LDL-cholesterol has been implicated in the aetiology of lipid related diseases including cardiovascular disease, obesity, diabetes and hypertension [21]. In Nigeria, there seems to be an inadequate knowledge and information regarding the AHA recommended dietary cholesterol allowance, even among the educated. Where the information is available it is not widely disseminated or practiced by those who possess the knowledge.

In this study, the results suggest that more of the female respondents have heard of the term "dietary cholesterol" as well as the negative effect of excess dietary cholesterol on cellular functions than their male counterparts. This might be 


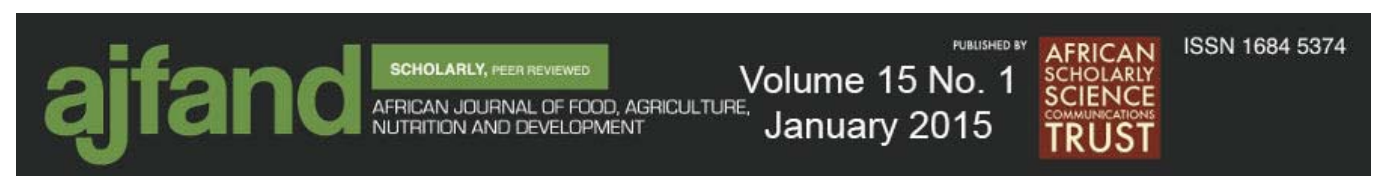

attributed to the point that majority of the respondents were students, and females of this category tend to be more health and appearance conscious. The consumption of meats, egg yolk, shrimps, whole milk and dairy products have been found to contribute to the overproduction or underutilization of LDL-cholesterol or it could be hereditary based such as genetic familial hypercholesterolemia or other metabolic syndrome such as type II diabetes [22].

The study showed that majority of the females ate poultry egg at least once a day than males. However, females tend to eat the egg white more than their male counterparts who consume more of the whole egg. In line with maintaining adequate dietary cholesterol practice, which is consumption of less than $300 \mathrm{mg}$ of cholesterol per day on average [23, 24], majority of the respondents neither checked their blood cholesterol level on regular basis nor knew the AHA recommended dietary cholesterol allowance. A previous study had also shown that non-vegetarians who ate a lot of animal products were more predisposed to having an elevated level of blood cholesterol and triglycerides [9]. The present study indicated that majority of the non-vegetarians ate the whole poultry egg than vegetarians. Respondents in science related discipline did not check their blood cholesterol level on regular basis, despite their awareness status on the negative effect of consuming high dietary and also they ate a lot of fried foods and confectionery. One explanation for these observations might be that majority of the respondents were students under the age range of 15 - 35 years of age who were still dependent on their parents for guidance for financial support.

Furthermore, the study revealed that those who were knowledgeable about the AHA recommended dietary cholesterol allowance still ate on regular basis foods rich in saturated fatty acids and trans-unsaturated fatty acids such as fried foods, ice cream, cakes and other confectionery. This might be due to inadequate information about sources of dietary cholesterol as well as the appropriate amount of dietary cholesterol to consume. Poverty could also be attributed to the above observation, the reason being that a lot people cannot afford foods with proven beneficial health factors such as fruits and vegetables or supplements like bioactive peptides with known hypocholesterolemic effects [25]. Foods rich in antioxidants have been reported by several authors to have positive impact in lowering blood cholesterol or preventing the elevation of blood cholesterol level [26].

Further studies revealed quantitatively, that the plasma total cholesterol, LDLcholesterol, triglyceride and glucose concentrations in males were slightly elevated compared to females while the HDL-cholesterol concentrations in males were reduced than in females. This might be due to the observed effect that females of the studied age category were more knowledgeable, nutrition= wise, and health conscious than their male counterparts. These females tend to be preoccupied with their physical appearance through exercises and choice of diet than their male counterparts. These in turn might have resulted in higher nutritional knowledge and application [27]. Previous findings had shown that exercise could help to some considerable extent to reduce the blood cholesterol concentrations [28]. 


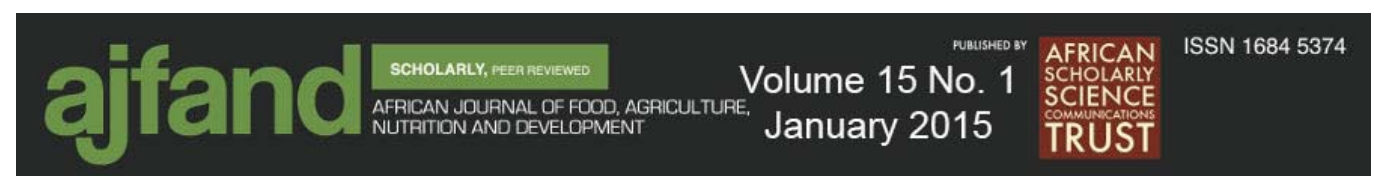

The measured Body Mass Index (BMI) of the volunteered participants showed that some of them were under the categories of normal body weight, overweight and obese in accordance to standard BMI. The plasma total cholesterol, LDL-cholesterol, triglyceride and glucose concentrations in normal weight category were found to be low compared to respondents in the overweight and obese categories. The plasma HDL-cholesterol concentrations in the normal weight category were elevated when compared with other categories. This suggests that the individuals in the normal body weight category might have a reduced risk of disease development while the overweight and obese categories were predisposed to high risk of disease development. This is also in agreement with previous reports that correlated reduced blood glucose, plasma total cholesterol, LDL-cholesterol, triglyceride and elevated HDL-cholesterol with normal body weight of individuals [29]. Increase in the blood cholesterol and glucose levels is an important risk factor in the development of coronary heart disease and diabetes [21]. High blood cholesterol level could be trapped on the arterial walls. Over time it builds up into a plaque. The plaque can narrow blood vessels, a condition called arteriosclerosis or hardening of the arteries; if the blood vessels of the heart are affected it could result in coronary heart or artery disease. If the coronary arteries are partly blocked by plaque, the blood may not be able to supply nutrients and oxygen to the heart muscle. This can cause chest pain or angina. Some cholesterol-rich plaques are unstable because of thin covering and can burst, releasing cholesterol and fat into the bloodstream; this can cause blood clot, blocking the blood flow through the artery eventually resulting in heart attack [24]. The reduction in plasma cholesterol concentration, mostly LDL and increased HDL, has been shown to reduce lipid related diseases and mortality from such diseases [30].

Further analysis showed that the plasma levels of HDL-cholesterol and LDLcholesterol in all categories correlated with the level of total cholesterol concentration. This is in agreement with previous findings [9]. The plasma glucose concentrations also correlated with the levels of plasma LDL cholesterol concentrations. This observation supported other findings that have implicated glucose metabolism in the aetiology of lipid related diseases as well as LDLcholesterol in the aetiology of glucose related diseases [29]. Findings from this study showed an inadequate awareness and practice of the AHA recommended dietary cholesterol allowance which could predispose individuals to majority of diseases including coronary heart disease, hypertension, obesity and diabetes. 


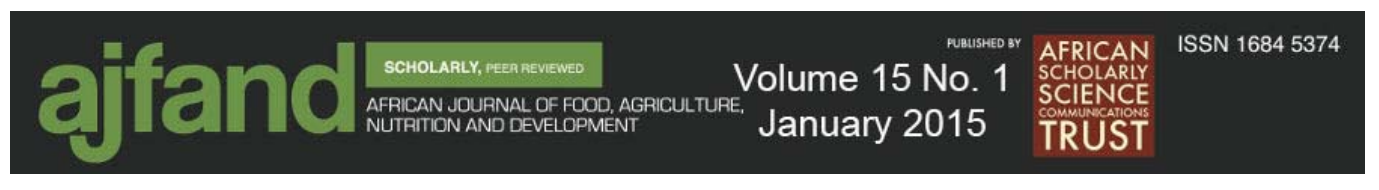

Table 1: Gender and age frequency on the awareness and practice of adequate dietary cholesterol consumption

\begin{tabular}{|c|c|c|c|c|c|c|c|c|c|c|c|c|c|c|}
\hline \multirow[b]{3}{*}{ PARAMEIERS } & \multicolumn{4}{|c|}{ Gender (\%) } & \multicolumn{10}{|c|}{ Age (\%) } \\
\hline & \multicolumn{2}{|c|}{ Male } & \multicolumn{2}{|c|}{ Female } & \multicolumn{2}{|c|}{$15-20$ (yrs) } & \multicolumn{2}{|c|}{$20-25$ (yrs) } & \multicolumn{2}{|c|}{$25-30$ (yrs) } & \multicolumn{2}{|c|}{$30-35$ (yrs) } & \multicolumn{2}{|c|}{35 and above (yrs) } \\
\hline & Yes & No & Yes & No & Yes & No & Yes & No & Yes & No & Yes & No & Yes & No \\
\hline CHOL Knowledge & 44.3 & 1.0 & 54.6 & 0.0 & 21.6 & 0.0 & 24.7 & 1.0 & 15.5 & 0.0 & 26.8 & 0.0 & 10.3 & 0.0 \\
\hline $\begin{array}{l}\text { CHOL Health } \\
\text { Impact }\end{array}$ & 27.8 & 11.3 & 35.1 & 9.3 & 17.5 & 1.0 & 15.5 & 6.2 & 8.2 & 6.2 & 14.4 & 5.2 & 7.5 & 2.1 \\
\hline PE Consumption & 41.2 & 4.1 & 50.5 & 4.1 & 20.6 & 1.0 & 24.7 & 1 & 13.4 & 2.1 & 23.7 & 3.1 & 9.3 & 1.0 \\
\hline FEconsumption & \multicolumn{2}{|c|}{$\begin{array}{c}5.2 \\
196\end{array}$} & \multicolumn{2}{|c|}{0.0} & & & \multicolumn{2}{|c|}{1.0} & \multicolumn{2}{|c|}{1.0} & \multicolumn{2}{|c|}{0.0} \\
\hline $\begin{array}{c}\text { Once a day } \\
\text { Once a week } \\
\text { Trice a week } \\
\text { Three times a week }\end{array}$ & & $\begin{array}{l}2 \\
6 \\
4 \\
2\end{array}$ & & & & $\begin{array}{c}1.0 \\
15.5 \\
5.2 \\
0.0\end{array}$ & & $\begin{array}{l}2.1 \\
9.3 \\
9.3 \\
5.2\end{array}$ & & & & & & \\
\hline E Part consumed & \multirow{2}{*}{\multicolumn{2}{|c|}{$\begin{array}{c}40.2 \\
5.2 \\
0\end{array}$}} & \multirow{2}{*}{\multicolumn{2}{|c|}{$\begin{array}{c}1.2 \\
12.4 \\
1\end{array}$}} & & & & & & & & & & \\
\hline $\begin{array}{l}\text { Whole egg } \\
\text { White part } \\
\text { Yellowyoke }\end{array}$ & & & & & & $\begin{array}{l}17.5 \\
4.1 \\
0.0\end{array}$ & & $\begin{array}{l}23.7 \\
2.1 \\
0.0\end{array}$ & & & & & & \\
\hline FCHOL checking & & & & & & & & & & & & & & \\
\hline $\begin{array}{c}\text { None } \\
\text { Sometimes } \\
\text { Regularly }\end{array}$ & & & $\begin{array}{l}1 \\
5 .\end{array}$ & & & $\begin{array}{c}19.6 \\
2.1 \\
0.0\end{array}$ & & $\begin{array}{l}20.6 \\
5.2 \\
0.0\end{array}$ & & & & & & \\
\hline RD cholesterol level & 13.4 & 32 & 26.8 & 27.8 & 10.3 & 11.3 & 11.3 & 14.3 & 7.2 & 8.2 & 6.2 & 20.6 & 5.2 & 5.2 \\
\hline Eat Fried food & 42.3 & 3.1 & 50.5 & 4.1 & 21.6 & 0.0 & 24.7 & 1.0 & 14.4 & 1.0 & 23.7 & 3.1 & 8.2 & 2.1 \\
\hline Eat confectionaries & & & & & & & & & & & & & & \\
\hline $\begin{array}{c}\text { Not at all } \\
\text { Sometimes } \\
\text { Regularly }\end{array}$ & & & & & & $\begin{array}{c}0.0 \\
14.4 \\
7.2\end{array}$ & & $\begin{array}{l}0.0 \\
8.6 \\
7.2\end{array}$ & & & & & & \\
\hline
\end{tabular}

CHOL-cholesterol; CHOL Health Impact: - indicates awareness of dietary cholesterol negative health implications; PEpoultry egg; FE-frequency of egg consumption; E-egg; F-frequency; RD-recommended dietary 


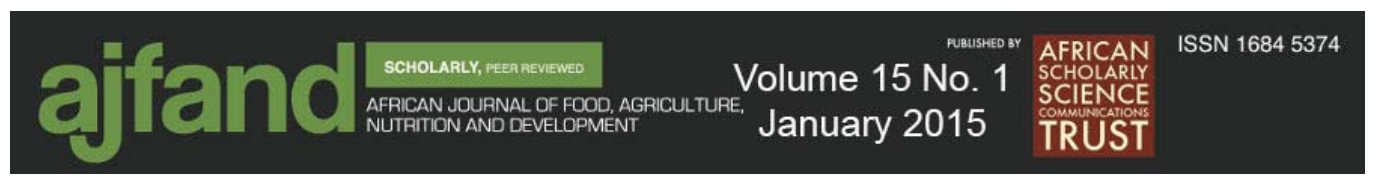

Table 2: Highest educational background and occupation frequency on the awareness and practice of adequate dietary cholesterol consumption

\begin{tabular}{|c|c|c|c|c|c|c|c|c|c|c|c|c|c|c|c|c|c|c|}
\hline \multirow[b]{3}{*}{ PARAMETERS } & \multicolumn{8}{|c|}{ Highest Educational background (\%) } & \multicolumn{10}{|c|}{ Occupation (\%) } \\
\hline & \multicolumn{2}{|c|}{ Primary } & \multicolumn{2}{|c|}{ Secondary } & \multicolumn{2}{|c|}{ Tertiary } & \multicolumn{2}{|c|}{ Vocational } & \multicolumn{2}{|c|}{ Teaching } & \multicolumn{2}{|c|}{ Non teaching } & \multicolumn{2}{|c|}{ Student } & \multicolumn{2}{|c|}{ Business } & \multicolumn{2}{|c|}{ Others } \\
\hline & Yes & No & Yes & No & Yes & No & Yes & No & Yes & No & Yes & No & Yes & No & Yes & No & Yes & No \\
\hline CHOL Knowledge & Nil & Nil & 3.1 & 0.0 & 84.5 & 1.0 & 11.3 & 0.0 & 24.7 & 0.0 & 8.2 & 0.0 & 56.7 & 1.0 & 6.2 & 0.0 & 3.1 & 0.0 \\
\hline $\begin{array}{c}\text { CHOL Health } \\
\text { Impact }\end{array}$ & Nil & Nil & 0.0 & 0.0 & 56.7 & 18.6 & 6.2 & 2.1 & 16.5 & 5.2 & 4.1 & 1.0 & 35.1 & 13.4 & 5.2 & 1.0 & 2.1 & 0.0 \\
\hline PE Consumption & Nil & Nil & 3.1 & 0.0 & 79.4 & 6.2 & 9.3 & 2.1 & 26.1 & 3.1 & 8.2 & 0.0 & 53.6 & 4.1 & 6.2 & 0.0 & 2.1 & 1.0 \\
\hline FE consumption & \multirow{2}{*}{\multicolumn{2}{|c|}{ Nil }} & \multirow{2}{*}{\multicolumn{2}{|c|}{$\begin{array}{l}1.0 \\
1.0 \\
1.0 \\
0.0\end{array}$}} & \multirow{2}{*}{\multicolumn{2}{|c|}{$\begin{array}{l}4.1 \\
48.5 \\
22.7 \\
10.3\end{array}$}} & & & & & & & & & & & & \\
\hline $\begin{array}{c}\text { Once a day } \\
\text { Once a week } \\
\text { Trice a week } \\
\text { Three times a week }\end{array}$ & & & & & & & \multicolumn{2}{|r|}{$\begin{array}{l}0.0 \\
6.2 \\
2.1 \\
3.1\end{array}$} & \multicolumn{2}{|c|}{$\begin{array}{c}1.0 \\
15.5 \\
4.1 \\
4.1\end{array}$} & \multicolumn{2}{|c|}{$\begin{array}{l}1.0 \\
5.2 \\
0.0 \\
2.1\end{array}$} & \multicolumn{2}{|c|}{$\begin{array}{c}3.1 \\
29.9 \\
18.6 \\
6.2\end{array}$} & \multicolumn{2}{|c|}{$\begin{array}{l}0.0 \\
3.1 \\
2.1 \\
1.0\end{array}$} & \multicolumn{2}{|c|}{$\begin{array}{l}0.0 \\
2.1 \\
1.0 \\
0.0\end{array}$} \\
\hline E Part consumed & \multirow{2}{*}{\multicolumn{2}{|c|}{ Nil }} & \multirow{2}{*}{\multicolumn{2}{|c|}{$\begin{array}{l}3.1 \\
0.0 \\
0.0\end{array}$}} & \multirow{2}{*}{\multicolumn{2}{|c|}{$\begin{array}{l}71.1 \\
14.4 \\
0.0\end{array}$}} & \multirow{2}{*}{\multicolumn{2}{|c|}{$\begin{array}{l}7.2 \\
3.1 \\
1.0\end{array}$}} & \multirow{2}{*}{\multicolumn{2}{|c|}{$\begin{array}{l}18.6 \\
6.2 \\
0.0\end{array}$}} & \multirow{2}{*}{\multicolumn{2}{|c|}{$\begin{array}{l}6.2 \\
2.1 \\
0.0\end{array}$}} & \multirow{2}{*}{\multicolumn{2}{|c|}{$\begin{array}{c}48.5 \\
8.2 \\
1.0\end{array}$}} & \multirow{2}{*}{\multicolumn{2}{|c|}{$\begin{array}{l}5.2 \\
1.0 \\
0.0\end{array}$}} & \multirow{2}{*}{\multicolumn{2}{|c|}{$\begin{array}{l}3.1 \\
0.0 \\
0.0\end{array}$}} \\
\hline $\begin{array}{l}\text { Whole egg } \\
\text { White part } \\
\text { Yellowyoke }\end{array}$ & & & & & & & & & & & & & & & & & & \\
\hline F CHOL checking & \multirow{2}{*}{\multicolumn{2}{|c|}{ Nil }} & \multirow{2}{*}{\multicolumn{2}{|c|}{$\begin{array}{l}2.1 \\
0.0 \\
1.0\end{array}$}} & & & & & & & & & & & & & & \\
\hline $\begin{array}{l}\text { None } \\
\text { Sometimes } \\
\text { Regularly }\end{array}$ & & & & & & & & $\begin{array}{l}6.2 \\
3.1 \\
2.1\end{array}$ & & $\begin{array}{l}5.5 \\
7.2 \\
1.0\end{array}$ & & & & & & $\begin{array}{l}0 \\
2 \\
0\end{array}$ & & $\begin{array}{l}0 \\
.0 \\
.0\end{array}$ \\
\hline RD cholesterol level & Nil & Nil & 1.0 & 2.1 & 34.0 & 51.5 & 5.2 & 6.2 & 8.2 & 16.5 & 4.1 & 4.1 & 23.7 & 34.0 & 4.1 & 2.1 & 0.0 & 3.1 \\
\hline Eat Fried food & Nil & Nil & 3.1 & 0.0 & 81.4 & 4.1 & 8.2 & 3.1 & 21.6 & 3.1 & 7.2 & 1.0 & 54.6 & 3.1 & 6.2 & 0.0 & 3.1 & 0.0 \\
\hline Eat confectionaries & & & & & & & & & & & & & & & & & & \\
\hline $\begin{array}{l}\text { Not at all } \\
\text { Sometimes } \\
\text { Regularly }\end{array}$ & & & & & & & & $\begin{array}{l}0.0 \\
9.3 \\
2.1\end{array}$ & & $\begin{array}{l}1.0 \\
2.6 \\
2.1\end{array}$ & & & & & & $\begin{array}{l}0 \\
2 \\
0\end{array}$ & & $\begin{array}{l}.1 \\
0.1 \\
7.8\end{array}$ \\
\hline
\end{tabular}

CHOL-cholesterol; CHOL Health Impact: - indicates awareness of dietary cholesterol negative health implications; PE-poultry egg; FE-frequency

of egg consumption; E-egg; F-frequency; RD-recommended dietary; Others:-any other type of occupation not mentioned 


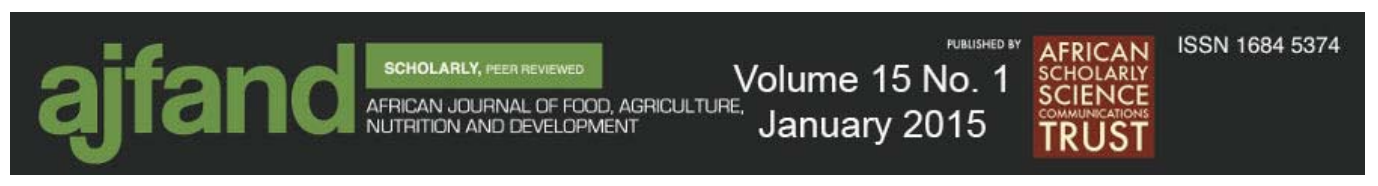

Table 3: Percentage of diet type and discipline frequency on the awareness and practice of recommended dietary cholesterol allowance

\begin{tabular}{|c|c|c|c|c|c|c|c|c|c|c|c|c|c|c|}
\hline \multirow[b]{3}{*}{ PARAMETERS } & \multicolumn{6}{|c|}{ Diet Type } & \multicolumn{8}{|c|}{ Discipline } \\
\hline & \multicolumn{2}{|c|}{$\begin{array}{l}\text { Vegetarian } \\
\text { (\%) }\end{array}$} & \multicolumn{2}{|c|}{$\begin{array}{c}\text { Non vegetarian } \\
\text { (\%) }\end{array}$} & \multicolumn{2}{|c|}{$\begin{array}{c}\text { Other Diet type } \\
\text { (\%) }\end{array}$} & \multicolumn{2}{|c|}{$\begin{array}{l}\text { Sciences } \\
\text { (\%) }\end{array}$} & \multicolumn{2}{|c|}{$\begin{array}{l}\text { Arts } \\
\text { (\%) }\end{array}$} & \multicolumn{2}{|c|}{$\begin{array}{c}\text { Social Sciences } \\
\text { (\%) }\end{array}$} & \multicolumn{2}{|c|}{$\begin{array}{l}\text { Other discipline } \\
\text { (\%) }\end{array}$} \\
\hline & Yes & No & Yes & No & Yes & No & Yes & No & Yes & No & Yes & No & Yes & No \\
\hline CHOL Knowledge & 11.3 & 0.0 & 77.3 & 1 & 10.3 & 0.0 & 76.3 & 1.0 & 5.2 & 0.0 & 12.4 & 0.0 & 5.2 & 0.0 \\
\hline CHOL Health Impact & 6.2 & 3.1 & 49.5 & 15.5 & 7.2 & 2.1 & 51.5 & 14.4 & 1.0 & 3.1 & 7.2 & 3.1 & 3.1 & 0.0 \\
\hline PEConsumption & 10.3 & 1.0 & 71.1 & 7.2 & 10.3 & 0.0 & 73.2 & 4.1 & 5.2 & 0.0 & 9.3 & 3.1 & 4.1 & 1.0 \\
\hline \multicolumn{15}{|l|}{ FEconsumption } \\
\hline $\begin{array}{c}\text { Once a week } \\
\text { Thice a week Three } \\
\text { times a week } \\
\text { Once a day }\end{array}$ & \multicolumn{2}{|c|}{$\begin{array}{l}6.2 \\
2.1 \\
3.1 \\
0.0\end{array}$} & \multicolumn{2}{|c|}{$\begin{array}{c}42.3 \\
23.7 \\
7.2 \\
5.2\end{array}$} & \multicolumn{2}{|c|}{$\begin{array}{l}7.2 \\
0.0 \\
3.1 \\
0.0\end{array}$} & \multicolumn{2}{|c|}{$\begin{array}{c}41.2 \\
21.6 \\
9.3 \\
5.2\end{array}$} & \multicolumn{2}{|c|}{$\begin{array}{l}3.1 \\
1.0 \\
1.0 \\
0.0\end{array}$} & \multicolumn{2}{|c|}{$\begin{array}{l}7.2 \\
2.1 \\
3.1 \\
0.0\end{array}$} & \multicolumn{2}{|c|}{$\begin{array}{l}4.1 \\
1.0 \\
0.0 \\
0.0\end{array}$} \\
\hline EPart consumed & \multirow{2}{*}{\multicolumn{2}{|c|}{$\begin{array}{l}9.3 \\
2.1\end{array}$}} & \multirow{2}{*}{\multicolumn{2}{|c|}{$\begin{array}{l}66.0 \\
11.3 \\
1.0\end{array}$}} & \multirow{2}{*}{\multicolumn{2}{|c|}{$\begin{array}{l}6.2 \\
4.1 \\
0.0\end{array}$}} & \multirow{2}{*}{\multicolumn{2}{|c|}{$\begin{array}{c}61.1 \\
15.5 \\
0.0\end{array}$}} & \multirow{2}{*}{\multicolumn{2}{|c|}{$\begin{array}{l}5.2 \\
0.0 \\
0.0\end{array}$}} & \multirow{2}{*}{\multicolumn{2}{|c|}{$\begin{array}{l}11.3 \\
1.0 \\
0.0\end{array}$}} & \multirow{2}{*}{\multicolumn{2}{|c|}{$\begin{array}{l}3.1 \\
1.0 \\
1.0\end{array}$}} \\
\hline $\begin{array}{l}\text { Whole egg } \\
\text { White part } \\
\text { Yellowyoke }\end{array}$ & & & & & & & & & & & & & & \\
\hline \multicolumn{15}{|l|}{ FCHOL checking } \\
\hline $\begin{array}{c}\text { None } \\
\text { Sometimes } \\
\text { Regularly }\end{array}$ & \multicolumn{2}{|c|}{$\begin{array}{l}9.3 \\
2.1 \\
0.0\end{array}$} & \multicolumn{2}{|c|}{$\begin{array}{l}55.7 \\
16.5 \\
6.2\end{array}$} & \multicolumn{2}{|c|}{$\begin{array}{c}7.2 \\
2.11 . \\
0\end{array}$} & \multicolumn{2}{|c|}{$\begin{array}{c}62.9 \\
12.4 \\
2.1\end{array}$} & \multicolumn{2}{|c|}{$\begin{array}{l}2.1 \\
1.0 \\
2.1\end{array}$} & \multicolumn{2}{|c|}{$\begin{array}{l}6.2 \\
5.2 \\
1.0\end{array}$} & \multicolumn{2}{|c|}{$\begin{array}{l}1.0 \\
2.1 \\
2.1\end{array}$} \\
\hline RD cholesterol level & 6.2 & 5.2 & 29.9 & 48.5 & 4.1 & 6.2 & 36.1 & 41.2 & 1.0 & 4.1 & 2.1 & 10.3 & 1.0 & 4.1 \\
\hline Eat Fried food & 11.3 & 0.0 & 71.1 & 7.1 & 10.3 & 0.0 & 73.2 & 4.1 & 5.2 & 0.0 & 10.3 & 2.1 & 4.1 & 1.0 \\
\hline Eat confectionaries & & & & & & & & & & & & & & \\
\hline $\begin{array}{l}\text { Not at all } \\
\text { Sometimes } \\
\text { Regularly }\end{array}$ & & & & & & 2.0 & & & & & & & & \\
\hline
\end{tabular}

CHOL-cholesterol; CHOL Health Impact: - indicates awareness of dietary cholesterol negative health implications; PE-poultry egg; FEfrequency of egg consumption; E-egg; F-frequency; RD-recommended dietary 


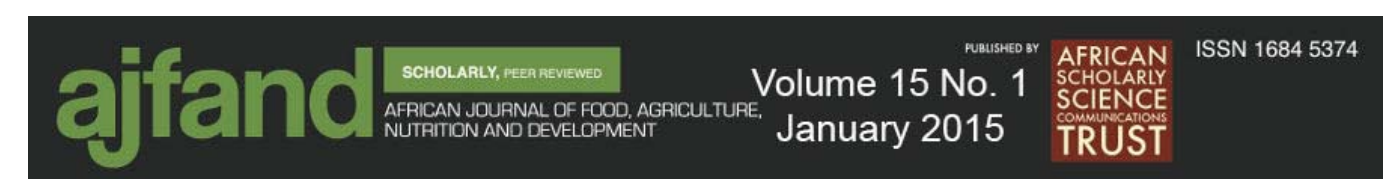

Table 4: Showing plasma lipids and glucose correlation

\begin{tabular}{|ccccc|}
\hline & & Plasma Parameters & & \\
\hline Total cholesterol (mg/d) & LDL-cholesterol & HDL-cholesterol & Triglyceride & Glucose \\
& $(\mathbf{m g} / \mathbf{d l})$ & $(\mathbf{m g} / \mathbf{d l})$ & $\mathbf{( m )}$ & \\
$141.44 \pm 49.10$ & $58.65 \pm 29.73$ & $41.55 \pm 43.284$ & $206.25 \pm 34.10$ & $49.66 \pm 16.83$ \\
& $\mathrm{P}=0.500^{\#}$ & $\mathrm{P}=0.802^{*}$ & $\mathrm{P}=0.430^{¥}$ & \\
\hline
\end{tabular}

\# indicates correlation with total cholesterol; *indicates correlation with total cholesterol; $¥$ indicates correlation with LDLcholesterol

P:-Person correlation coefficient considered significant $\mathrm{P}<0.05$ 


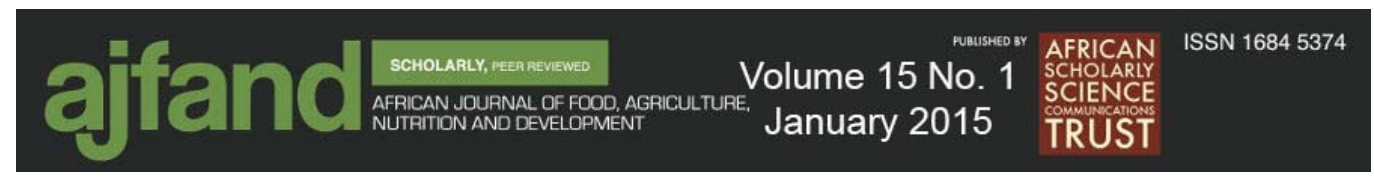

\section{REFERENCES}

1. Ikonen E Cellular cholesterol trafficking and compartmentalization. Nature Reviews Molecular Cell Biology 2008; 9: 125 - 38.

2. Goldstein JL, DeBose-Boyd RA and MS Brown Protein sensors for membrane sterols. Cell 2006; 124: 35 - 46.

3. Greenfeder $\mathbf{S}$ Emerging strategies and agents to lower cardiovascular risk by increasing high density lipoprotein cholesterol levels. Current MedicalChemistry 2009; 16: 144 - 56.

4. Chang T, Chang CC, Ohgami $\mathbf{N}$ and $\mathbf{Y}$ Yamauchi Cholesterol sensing, trafficking, and esterification. Annual Review on Cell and Developmental Biology 2006; 22:129 -157.

5. Gaziano TA, Bitton A, Anand S, Abrahams-Gessel S and A Murphy Growing Epidemic of Coronary Heart Disease in Low- and Middle-Income Countries. Current Problems Cardiology 2010; 35(2): 72 - 115. doi:10.1016/j.cpcardiol.2009.10.002.

6. World Health Organization World Health Statistics. WHO, 2008: Ginebra. http://www.who.pdf. Retrieved on 12th April, 2012.

7. Ooi $\mathbf{L}$ and $\mathbf{M}$ Liong Cholesterol lowering effects of probiotic and prebiotics: a review on in vivo and in vitro findings. International Journal of Molecular Sciences 2010; 11: 2499-2522.

8. WHO. Diet, Nutrition and Prevention of Chronic Diseases; Report of a Joint WHO/FAO Expert Consultation, Geneva, Switzerland, 2003.

9. Anyasor GN, Adeseye LO, Ogunnowo AA and LO Erukainure Lipid profile and oxidative stress status in vegetarians. Pakistan Journal of Medical Sciences 2011; 27(2): 409 - 413.

10. Chung-Tung JL and TY Stephen Knowledge of dietary fats among US consumers. Journal of American Dietetic Association 2010; 110: 613 - 618.

11. Jenkins DJ, Jones PJ, Lamarche B, Kendall CW, Faulkner D, Cermakova L, Gigleux I, Ramprasath V, Souza R, Ireland C, Patel D, Srichaikul K, Abdulnour S, Bashyam B, Collie C, Hoshizaki S, Josse RG, Leiter L, Connelly PW and J Frohlich Effect of a dietary portfolio of cholesterollowering foods given at 2 levels of intensity of dietary advice on serum lipids in hyperlipidemia a randomized controlled trial JAMA 2011; 306(8): 831 - 839. 


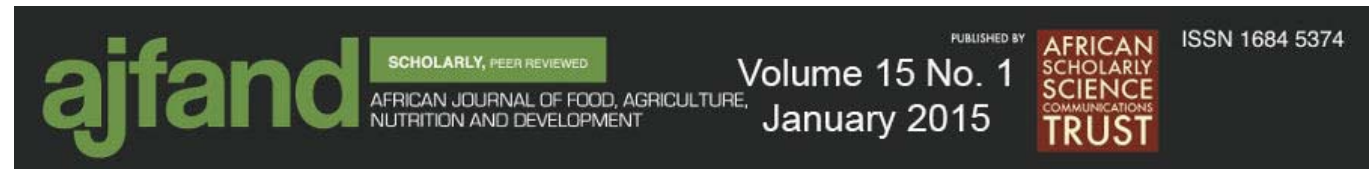

12. Krauss RM, Eckel RH, Howard B, Appel LJ, Daniels SR, Deckelbaum RJ, Erdman JW, Etherton PK, Goldberg IJ, Kotchen TA, Lichtenstein AH, Mitch WE, Mullis R, Robinson K, Wylie-Rosett J, Jeor S, Suttie J, Tribble DL and TL Bazzarre AHA Dietary Guidelines: revision 2000: a statement for healthcare professionals from the nutrition committee of the American Heart Association. Circulation 2000; 102: 2284 - 2299.

13. Zazpe I, Beunza JJ, Bes-Rastrollo M, Warnberg J, de la Fuente-Arrillaga C, Benito S, Va'zquez $Z$ and MA Martı'nez-Gonza'lez Egg consumption and risk of cardiovascular disease in the SUN Project. European Journal of Clinical Nutrition 2011; 1 - 7 .

14. Djousse $\mathbf{L}$ and $\mathbf{J}$ Gaziano Egg consumption in relation to cardiovascular disease and mortality: the physician health study. American Journal of Clinical Nutrition 2008; 87: 964 - 969.

15. Qureshi AI, Suri FK, Ahmed S, Nasar A and AA Divani Regular egg consumption does not increase the risk of stroke and cardiovascular diseases. Medical Science Monitor 2007; 13:1 - 8.

16. FDA. U.S Food and Drug Administration. FDA's plan to tackle U.S. obesity 2004. Retrieved April 12, 2012 from

http://www.fda.gov/oc/opacom/hottopics/obesity plan.html.

17. IFIC. Fitting dietary fats into a healthful diet-A consumer point of view. A report to IFIC Foundation, September 2004. IFIC Foundation Website. http://www.ific.org/research upload/Fitting Dietary Fats into a Healthful Diet. Retrieved on 12th April, 2012.

18. Contento IR Nutrition Education: Linking Research, Theory, and Practice. Jones and Bartlett Publishers, Boston. 2007: 309.

19. Friedewald WT, Levy RI and DS Fredrickson Estimation of the concentration of low density lipoprotein cholesterol in plasma without the use of preparative ultracentrifuge. Clinical Chemistry 18: 499 - 502.

20. Hill JO, Catenacci VA and HR Wyatt Obesity: Etiolog. In: Shil ME, Shike M, Rose AC, Caballero B and RJ Cousins (Eds). Modern Nutrition in Health and Disease. Baltimore: Lippincott Williams and Wilkins, 2006: 1014 - 1028.

21. Gavez AF, Chunjiang F, Porter J and M Kerley Cholesterol-lowering property of a chromatin-binding peptide derived from soy 2011. http://www.lunasin.com/research.aspx retrieved on 2nd April, 2012.

22. Goldstein JL and MS Brown The LDL receptor. Arteriosclerosis Thrombosis and Vascular Biology 2009; 29:431-438. 


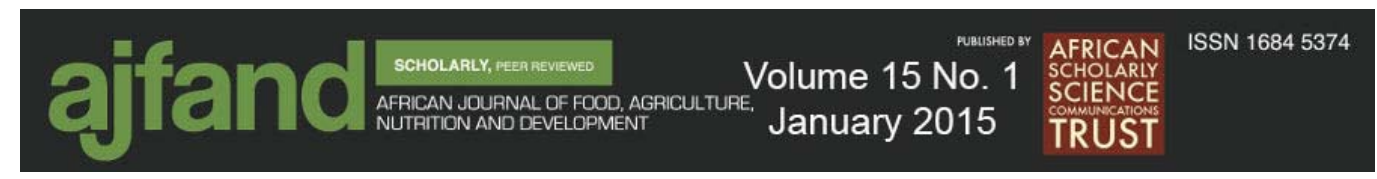

23. Nagaoka S Cholesterol-Lowering Proteins and Peptides. In: Mine Y and F Shahidi (Eds). Nutraceutical Proteins and Peptides in Health and Disease. Taylor and Francis, Boca Raton 2006: 41- 67.

24. National Institutes of Health (NIH) Your guide to lower cholesterol with therapeutic lifestyle changes National Heart, Lung, and Blood Institute, 2005 NIH Publication No. 065235.

25. Dianne A and DA Hyson A Comprehensive Review of Apples and Apple Components and Their Relationship to Human Health American Society for Nutrition. Advances in Nutrition. 2011; 2: 408 - 420 doi:10.3945/an.111.000513.

26. Sabita NS and OT Trygve The Role of Nutraceuticals in Chemoprevention and Chemotherapy and Their Clinical Outcomes. Journal of Oncology 2012; 23 doi:10.1155/2012/192464.

27. Pirouznia M The association between nutrition knowledge and eating behavior in male and female adolescents in the US. International Journal of Food Sciences \& Nutrition, 2001; 52: 127 - 132.

28. Michel B, Fabricio AV, Ricardo VL and BA Fulvia Oxidative stress in rats exercised at different intensities. Journal of Chinese Medicine 2009; 4(1): 11 18.

29. Scott MG, Susanna H, David S A and DW Sean High density lipoprotein: it's not just about lipid transport anymore Trends Endocrinology and Metabolism 2011; 22(1): 9 - 15.

30. Zhang LH, Kamanna VS, Zhang MC and ML Kashyap Niacin inhibit surface expression of ATP synthase b chain in HepG2 cells: implications for raising HDL. Journal of Lipid Research 2008; 49: 1195 - 1201. 